were little in evidence, and there were no epidemics beyond minor outbreaks of mild influenza and pharyngitis. Nor was there any sign among the military population of the steady increase in tuberculosis which appeared to be occurring in the civilian population.

\section{George Green Centenary}

George Green, author of the famous "Essay on the Application of Mathematical Analysis to the Theories of Electricity and Magnetism", in which appeared for the first time what is now known as Green's theorem, died at Nottingham on May 31, 1841. The circumstances in which a miller was able to engage in mathematical research of fundamental importance have always puzzled the scientific world. New light has been thrown on the problem by $\mathrm{Mr}$. H. G. Green, who has been investigating the matter for several years. In a lecture delivered at University College, Nottingham, to commemorate the centenary, he showed that at least one resident in the locality was well acquainted with the works of the great French mathematicians Laplace and Lagrange, and that the library of the Bromley House Society, of which Green was a member, had no difficulty, even in time of war, in obtaining copies of their researches. Among the members of this Society were several men of high learning and culture, who subscribed for the publication of Green's Essay in 1828. A full account of the investigations will be published in Osiris, the journal of the history of science, in due course.

\section{Two French Botanical Pioneers}

The Botanical Garden at Montpellier has grown under the ægis of many distinguished botanists, some of whom made vast contributions to the science without the éclat of fame. Dora Maw provides, in a recent article (J.Roy. Hort. Soc., 66, Pts. 4 and 5, April and May 1941), a chapter of history which shows in vivid fashion the work of two earlier directors of the Montpellier Garden. Pierre Richer de Balleval (1564-1632) was the actual founder, and was a vigorous exponent of the rising science of pharmacognosy. He gathered together a consocies of 1,332 species, lost them during the military manœuvres of inter-religious strife, and started again with characteristic determination. Modern pharmacy owes to him the discovery of galenicals such as Aristolochia longa, Artemisia campestris and Scrophularia aquatica. Pierre Mario Auguste Broussonet (1761-1807) was a native of Montpellier, and became director of the gardens after a life of epic adventure. He travelled restlessly in south-western Europe and North Africa, after a thrilling succession of political reverses from posts of honour to expedient incarceration. Botanical awareness marked all his journeys, for he brought back knowledge of many useful plants-Tetraclinis articulata (citrus wood), Argania spinosa (iron-wood), Acacia gummifera (the source of gum arabic), and many species of medicinal value. His tenure of the directorship was relatively short, but the background of his extensive travels made it illustrious.

\section{Statistics in Public Policy}

Mr. H. W. Macrosty's inaugural presidential address to the Royal Statistical Society, which has now appeared in the Journal of the Society, in reviewing the evolution of official statistics in the last fifty years or so, emphasizes their importance for post. war reconstruction. Policy can only be sound if it is founded on a reliable ascertainment of all the facts. Society is never static; our theories must explain and conform to changes which appear to be spontaneously generated and our records must keep step with the changes. No trade policy has any chance of success which is not founded on the most careful study and understanding of the facts, and although the Economic Section of the League of Nations has already provided us with useful comparative studies of the course of international trade in the last twenty years, these do not appear to have penetrated far beyond the study and the lecture room.

Mr. Macrosty also doubts whether we have exhausted the methods of statistical analysis of trade data and whether something more of importance might be learned by the application of some of the methods of modern mathematical research. It is certain that, in the future, nutrition must form the basis of policy, even of international trade, and the repercussion of different lines of policy on each other must be carefully watched. Despite the researches of the last few years, we have still much to learn, and in the collection and study of what is yet unknown, as well as of what is at present known, statisticians are needed for the service of the future. Referring to gaps in our knowledge, Mr. Macrosty pointed out that we have still no quinquennial census; we know little about the distribution of incomes assessed for income tax except in the topmost range ; we have no reliable figures of working class earnings and expenditure; calculations of the national income and of savings require much estimation; we have no census of distribution and the monetary and other suggestions of the Macmillan report have not all been adopted although nine years have passed. These statistics are of the most intimate importance for the determination of public policy.

\section{Neanderthal Remains from Hither Asia}

THE current number of Antiquity as usual contains several important papers. These include among others an article on "The Viking Taste in PreConquest England" with excellent illustrations, and an account of "A Datable Ritual Barrow in Glamorganshire" by Sir Cyril Fox. But perhaps the most important information appears under the "Notes and News" and concerns a prehistoric find in Uzbekistan of flake tool industries associated with the remains of a Neanderthal child. Those who would like more details than this excellent précis can give should consult Asia (July and August, 1940) where A. P. Okladnikov has published two interim reports. The discovery itself was made in an immense rockshelter called Teshik-Tash high up in the side of the Zautolosh Darya gorge not far from Tashkent and the Soviet-Afghan frontier. The rock-shelter is 